\title{
Quality of Cherry Tomato Fruits under Conditions of Water and Saline Stress
}

\author{
Hurtado-Salazar A ${ }^{2 *}$, Torres J² and Ceballos-Aguirre $\mathrm{N}^{2}$ \\ University of Caldas, Department of Agricultural Production, University of Caldas, \\ Manizales, Caldas, Colombia
}

*Corresponding author: Alejandro Hurtado-Salazar, University of Caldas, Department of

Research Article

Volume 3 Issue 4

Received Date: June 06, 2018

Published Date: July 16, 2018

Agricultural Production, University of Caldas, Manizales, Caldas, Colombia; Tel: 57 68781500; Email: alhuza@gmail.com

\section{Abstract}

Tomato plants are a glycophyte species, characterized by being moderately sensitive to salinity, with negative effects on the development of plants, production and fruit quality under conditions of water and saline stress. The objective of the present study was to evaluate the quality of the cherry tomato fruits of nine elite introductions under conditions of water and saline stress. The experimental design was of subdivided plots, where the largest plot was comprised by the salinity level $\left(2.5,5.0\right.$ and $\left.7.5 \mathrm{dS} \mathrm{m}^{-1}\right)$ and the smallest plot was the substrate humidity level of $100 \%, 66 \%$ and $33 \%$. Nine tomato introductions and a commercial control (Sweet Million) were randomly arranged within each condition, with 4 repetitions. The variables evaluated were the following: relationship of equatorial (ED) and polar diameters (ED / PD), fruit firmness (FF), number of locules (NLF), soluble solids ( ${ }^{\circ}$ brix), titratable acidity, and production per plant (PPP). High levels of salinity and water stress promote the increase of brix degrees in cherry tomato fruits, but production decreases as abiotic stress increases. The production limit under saline stress conditions was $5 \mathrm{dS} \mathrm{m}^{-1}$ of the materials evaluated. Elite introductions IAC 1686 and IAC 1688 were those that presented the best average productions per plant with $498 \mathrm{~g}$ and $428 \mathrm{~g}$, respectively.

Keywords: Abiotic Stress; Stress Physiology; Production; Quality; Solanum Lycopersicum

\section{Introduction}

Among the alternatives to meet the rising global demand for food are greater exploitation of sowing between production cycles-which most of the time generates lower production, productivity increase, and expansion of cultivation areas, an alternative that guarantees greater food production and is still viable in some emerging countries such as Brazil and Colombia. In this context, a significant fraction of agricultural crops may be carried out in soils of marginal areas which, in their majority, present low fertility [1].
Salinity is one of the main factors that reduce the productivity of crops in the world [1]. The largest areas affected by salts are found in North and Central America and South Asia. In South America, the area affected by salts is approximately 85 million hectares, contemplating saline and sodic soils. In Brazil, in addition to the northeast region, there are saline soils in Rio Grande do Sul and the Pant anal Mato-grossense [2]. According to the same authors, based on the soil map of Brazil, soils compromised by salts occupy about $160,000 \mathrm{~km}^{2}$ or $2 \%$ of the national territory. Most of this area is located in the 


\section{Food Science and Nutrition Technology}

State of Bahia (44\% of the total), followed by Ceara with $26 \%$ of the total.

The soils susceptible to salinization in Colombia are covering an area of $86,592 \mathrm{~km}^{2}$, of which $78,277 \mathrm{~km}^{2}$ are in dry areas, that is, $90.39 \%$. The areas susceptible to salinization cover a large part of the Caribbean region, the valleys (Magdalena and Cauca rivers) and the highlands where the intensive agricultural production of the country is currently planned to expand [3].

About $20 \%$ of the cultivated areas and $33 \%$ of the irrigated areas in the world, especially in Asia, are affected by excess in salts [4]. The total area with salinity in the world is around one billion hectares. All continents, except Antarctica, have soil salinization [5]. The same authors report that this salinization is increasing at a rate of $10 \%$ per year.

Soils affected by salts are defined as those adversely modified for the growth of most species by the presence of soluble salts, exchangeable sodium or both in the root zone [6].

Soluble salts normally consist of various proportions of cations $\mathrm{Ca}^{2+}, \mathrm{Mg}^{2+}, \mathrm{Na}^{2+}$, anions $\mathrm{Cl}-\mathrm{SO}_{4}{ }^{2-}, \mathrm{HCO}_{3}{ }^{-}$and sometimes $\mathrm{K}^{+}, \mathrm{CO}_{3}{ }^{2-}$, y $\mathrm{NO}_{3}$. Soils affected by these salts are common in arid and semi-arid regions due to low rainfall and high evaporation [7]. Salinity can affect the absorption of $\mathrm{Ca}^{2+} \mathrm{y} \mathrm{K}^{+}$, depending on the species and the level of salinity [8].

Tomato plants are a glycophyte species, characterized by being moderately sensitive to salinity and their tolerance threshold is $2.5 \mathrm{dS} \mathrm{m}^{-1}$ [9]. In addition to the problem of saline soils, water scarcity is directly associated with this problem that considerably affects the production of most commercial crops [10]. The promising plant materials play an important role due to their high genetic variability, which allow them to adapt to marked conditions of abiotic stress, maintaining their production and quality.

At present, the effect of abiotic stress conditions on the quality of the fruits for the promising species of wild cherry tomato is unknown; thus, the objective of the present study was to evaluate the quality of cherry tomato fruits under conditions of water and saline stress.

\section{Materials and Methods}

The study was conducted in the area of hydroponic production of the University of Caldas, located in the city of Manizales (Caldas-Colombia) with coordinates $5^{\circ}$ $03^{\prime} 23.31^{\prime \prime} \mathrm{N}$ and $75^{\circ} 29^{\prime} 41.56^{\prime \prime} \mathrm{W}$, with an average temperature of $14^{\circ} \mathrm{C}$, height above sea level of $2,130 \mathrm{~m}$ and relative humidity of $78 \%$.

The plant material evaluated consisted of nine introductions of elite cherry tomato: LA1480, LA3652, LA445, IAC424, IAC1621, IAC426, IAC1686, IAC1688 and IAC1624, previously selected for their fruit production and quality. The Sweet Million hybrid was used as a control. The experimental design was completely random, in an arrangement of subdivided plots, where the largest plot was the salinity level $\left(2.5 \mathrm{dS} \mathrm{m}^{-1}, 5.0 \mathrm{dS} \mathrm{m}^{-1}, 4 \mathrm{dS} \mathrm{m}^{-1}\right.$ and $7.5 \mathrm{dS} \mathrm{m}^{-1}$ ) and the smallest plot was the level of water saturation of the substrate in relation to the requirement of the crop (100\%, 66\% and 33\%). Nine randomly arranged introductions of tomato and the commercial control (Sweet Million) were set within each condition and combination, with 4 repetitions. The tomato seedlings were sown in hydroponic beds (gutters) to a single stem with planting distances of $30 \mathrm{~cm}$ between seedlings, with distribution of double furrows at $30 \mathrm{~cm}$ between them, at $100 \mathrm{~cm}$ between lanes and at a height of $80 \mathrm{~cm}$ from the ground.

At the time of planting, trays of 128 locules were used for each of the elite introductions, after disinfection of trays with a solution of agricultural Iodine (5 cc / liter), which were immersed for 1 minute in this solution. The substrate used was peat Klasman ${ }^{\circledR}$ (No 3), inoculated with Trichoderma sp $\AA\left(8 \mathrm{~g} \mathrm{~L}^{-1}\right)$, the duration of this phase of planting was 23 days on average.

Subsequently, the plants were transferred to hydroponic beds $6 \mathrm{~m}$ long and $1.2 \mathrm{~m}$ wide to guarantee the irrigation sheet according to the treatments (percentage of water saturation $100 \%, 66 \%$ and $33 \%$ and saturation levels of salts $2.5 \mathrm{dS} \mathrm{m}^{-1}, 5.0 \mathrm{dS} \mathrm{m}^{-1}$ and $7.5 \mathrm{dS}$ $\mathrm{m}^{-1}$ ), according to the experimental design. A vertical trellis system was used, with 12 gauge galvanized wire, 2 $\mathrm{m}$ from the ground of the hydroponic bed of the greenhouse. The plants were driven on a single stem, with weekly pruning of the lateral branches. The cutting of the apical bud of the plants was done when they reached the height of the guardian thread ( $2.2 \mathrm{~m}$ in height).

The universal nutrient solution of Hoagland and Arnon modified, composed of $\mathrm{KH}_{2} \mathrm{PO}_{4} ; \mathrm{KNO}_{3} ; \mathrm{MgCl}_{2}$. $6 \mathrm{H}_{2} \mathrm{O}$; $\mathrm{MgSO}_{4} .7 \mathrm{H}_{2} \mathrm{O} ; \mathrm{CaCl}_{2} .2 \mathrm{H}_{2} \mathrm{O} ; \mathrm{CaSO}_{4} .2 \mathrm{H}_{2} \mathrm{O} ; \mathrm{NaNO}_{3} ; \mathrm{NH}_{4} \mathrm{NO}_{3}$; Fe-EDTA; $\mathrm{H}_{3} \mathrm{BO}_{3} ; \mathrm{ZnSO}_{4}$. $7 \mathrm{H}_{2} \mathrm{O} ; \mathrm{CuSO}_{4} .5 \mathrm{H}_{2} \mathrm{O} ; \mathrm{MnCl}_{2}$. $4 \mathrm{H}_{2} \mathrm{O}$; and $\mathrm{NaMoO}_{4} \cdot 2 \mathrm{H}_{2} \mathrm{O}$. to guarantee the salinity of the treatment, each solution was brought to a value of $2.5 \mathrm{dS}$ $\mathrm{m}^{-1} ; 5.0 \mathrm{dS} \mathrm{m} \mathrm{m}^{-1}$; and $7.5 \mathrm{dS} \mathrm{m}^{-1}$, with the addition of 
reactive level sodium chloride ( $99.9 \%$ purity). To evaluate the interaction between the percentage of water saturation and salinity, the different treatments of electrical conductivity ( $2.5 \mathrm{dS} \mathrm{m}-1,5.0 \mathrm{dS} \mathrm{m}-1$, and $5.5 \mathrm{dS}$ $\mathrm{m}-1$ ) were added to the percentages of water of $100 \%$, $66 \%$ and $33 \%$ for each of the experimental units of the elite introductions evaluated.

The equatorial (ED) and polar (PD) diameters were evaluated with the help of a digital caliper with $0.001 \mathrm{~mm}$ accuracy. Fruit firmness (FF) in pounds (lb.) was measured in the equatorial region of one of the faces of each fruit using a digital Effegi penetrometer (TF-011) with a tip of $8 \mathrm{~mm}$ in diameter. Number of locules (NL) by direct counting. The content of soluble solids (SS) in ${ }^{\circ}$ brix of the juice squeezed manually from the equatorial side of each fruit was determined using an ATAGO digital refract meter (Palette PR-101) and the production per plant (PPP).

The means were compared using Tukey's test, with a reliability level of $95 \%$. The regression analysis for each of the quantitative variables evaluated was carried out using the statistical package SAS.

\section{Results and Discussion}

Each of the evaluated variables was affected by saline and water stress conditions in each of the elite cherry tomato introductions. It should be noted that in the conditions of more severe salt stress $\left(7.5 \mathrm{dS} \mathrm{m}^{-1}\right)$ and the different interactions with the humidity of the substrate $(100,66$ and 33\%), none of the introductions reached the production stage, hence, no fruits were obtained as a sample. Therefore, the cherry tomato production limit for the 10 introductions studied is up to $5 \mathrm{dS} \mathrm{m}^{-1}$ of electrical conductivity.

\section{Relation equatorial and polar diameters (ED / PD)}

The relation equatorial and polar diameter (ED / PD) of the elite introductions have a flattened fruit format $(<1)$ for the different interactions, either under normal conditions or in $100 \%, 66 \%$ and $33 \%$ humidity (Table 1 ). The interaction of the shape of the fruit with the different concentrations of salinity evidenced that at concentrations of $1.5 \mathrm{dS} \mathrm{m}^{-1}$, the values are $1.04(>1)$, which indicates that the fruits are in greater proportion elongated according to the classification suggested by Hurtado-Salazar et al. (2015) [11] (Table 1). Likewise, in the condition with $2.5 \mathrm{dS} \mathrm{m}^{-1}$, the relation ED / PD was 0.97, corresponding to the one that most closely resembles the round shape that both consumers and the market demand (Table 1). In general, the values are close to $1(1 \pm 0.06)$ (Table 1$)$, which determines a round fruit shape, which is more attractive for the fresh market, as well as for its easy packaging and transport without suffering mechanical damage.

\begin{tabular}{|c|c|c|c|c|c|c|}
\hline \multirow{2}{*}{ Condition } & \multirow{2}{*}{ ED/PD } & FF & \multirow{2}{*}{ N. of locules } & \multirow{2}{*}{$\begin{array}{c}\text { SS } \\
\text { ('brix) }\end{array}$} & \multirow{2}{*}{$\begin{array}{c}\text { Acidity } \\
\text { (gr/ } 100 \text { gr ofCitric a.) }\end{array}$} & \multirow{2}{*}{$\begin{array}{l}\text { Production } \\
\text { (gr plant }^{-1} \text { ) }\end{array}$} \\
\hline & & (lb.) & & & & \\
\hline \multicolumn{7}{|l|}{ Humidity (\%) } \\
\hline 100 & $0.98 \mathrm{a}$ & $1045.81 \mathrm{~b}$ & $2.11 \mathrm{a}$ & $8.48 \mathrm{c}$ & $0.81 \mathrm{~b}$ & $403.92 \mathrm{a}$ \\
\hline 66 & $0.96 a$ & $1149.52 \mathrm{a}$ & $2.06 a$ & $10.31 a$ & $1.20 \mathrm{a}$ & $223.04 b$ \\
\hline 33 & $0.98 a$ & $1060.49 \mathrm{~b}$ & $2.07 a$ & $10.08 \mathrm{~b}$ & $1.04 \mathrm{a}$ & $150.05 c$ \\
\hline \multicolumn{7}{|l|}{ Salinity $\left(\mathrm{dS} \mathrm{m}^{-1}\right)$} \\
\hline 1,5 & $1.04 \mathrm{a}$ & $922.58 c$ & $2.19 a$ & $6.07 \mathrm{c}$ & $0.51 \mathrm{~b}$ & $686.28 \mathrm{a}$ \\
\hline 2,5 & $0.97 \mathrm{~b}$ & $1137.38 a$ & $2.08 \mathrm{~b}$ & $9.65 b$ & $1.02 \mathrm{a}$ & $343.73 b$ \\
\hline 5 & $0.94 \mathrm{c}$ & $1067.86 \mathrm{~b}$ & $2.04 \mathrm{~b}$ & $10.67 a$ & $1.16 \mathrm{a}$ & $74.86 c$ \\
\hline C.V & 11.43 & 21.44 & 13.8 & 10.99 & 41.25 & 51.29 \\
\hline
\end{tabular}

Table 1: Influence of humidity and salinity in the relation equatorial diameter - polar diameter (ED / PD), firmness of the fruit (FF), number of locules (NL), the relation FF / NL, soluble solids (SS), acidity and production per plant in 10 cherry tomato introductions in Manizales, Caldas, Colombia.

*Values followed by different letters differ significantly $(\mathrm{P}<0.05)$, according to the Duncan's test.

For the case of the introductions, IAC 1624 was the one that obtained the best relation (ED / PD) with values of 0.99 , reaching the round shape, while the highest value, and therefore representing elongated fruit, was for the introductions LA 1480 and LA 445, both with a relation of 1.07. The lowest values were for IAC 426 with a relation of 0.75 , therefore, with a flatter fruit shape than the other introductions (Table 2). 
Food Science and Nutrition Technology

\begin{tabular}{|c|c|c|c|c|c|c|}
\hline \multirow{2}{*}{ Introduction } & \multirow{2}{*}{ ED/PD } & Firmness of the fruit & \multirow{2}{*}{ N. ofLocules } & Brix degrees & Acidity & Production \\
\cline { 7 - 7 } \cline { 6 - 7 } & & $\mathbf{l b .}$ & $\mathbf{(}$ ) & (gr/ 100 gr of Citric a.) & (gr plant $^{-1}$ ) \\
\hline & & & & & & \\
\hline LA 3652 & $0.91 \mathrm{~d}$ & $1144.30 \mathrm{~b}$ & $2.08 \mathrm{~b}$ & $8.89 \mathrm{~d}$ & $0.71 \mathrm{a}$ & $170.12 \mathrm{~d}$ \\
\hline IAC 1688 & $1.06 \mathrm{~b}$ & $1096.15 \mathrm{c}$ & $2.19 \mathrm{a}$ & $8.61 \mathrm{e}$ & $0.86 \mathrm{a}$ & $428.44 \mathrm{a}$ \\
\hline IAC 1621 & $1.05 \mathrm{~b}$ & $1110.77 \mathrm{c}$ & $2.10 \mathrm{~b}$ & $10.21 \mathrm{a}$ & $1.06 \mathrm{a}$ & $297.62 \mathrm{c}$ \\
\hline IAC 424 & $0.84 \mathrm{e}$ & $940.96 \mathrm{~d}$ & $2.16 \mathrm{a}$ & $9.80 \mathrm{~b}$ & $1.05 \mathrm{a}$ & $182.27 \mathrm{~d}$ \\
\hline IAC 426 & $0.75 \mathrm{f}$ & $1217.58 \mathrm{a}$ & $2.10 \mathrm{~b}$ & $9.45 \mathrm{c}$ & $1.06 \mathrm{a}$ & $256.07 \mathrm{c}$ \\
\hline LA 1480 & $1.07 \mathrm{a}$ & $903.04 \mathrm{~d}$ & $2.02 \mathrm{c}$ & $9.10 \mathrm{~d}$ & $0.90 \mathrm{a}$ & $82.43 \mathrm{e}$ \\
\hline TESTIGO & $1.03 \mathrm{~b}$ & $972.45 \mathrm{~d}$ & $2.05 \mathrm{c}$ & $10.17 \mathrm{a}$ & $1.03 \mathrm{a}$ & $387.41 \mathrm{~b}$ \\
\hline IAC 1686 & $1.05 \mathrm{~b}$ & $1062.86 \mathrm{c}$ & $2.05 \mathrm{c}$ & $9.91 \mathrm{~b}$ & $1.00 \mathrm{a}$ & $498.19 \mathrm{a}$ \\
\hline LA 445 & $1.07 \mathrm{a}$ & $1128.33 \mathrm{~b}$ & $2.01 \mathrm{c}$ & $7.43 \mathrm{f}$ & $0.85 \mathrm{a}$ & $189.58 \mathrm{~d}$ \\
\hline IAC 1624 & $0.99 \mathrm{c}$ & $1098.61 \mathrm{c}$ & $2.03 \mathrm{c}$ & $9.95 \mathrm{~b}$ & $1.01 \mathrm{a}$ & $231.27 \mathrm{c}$ \\
\hline C.V & 11.43 & 21.44 & 13.8 & 10.99 & 41.25 & 51.29 \\
\hline
\end{tabular}

Table 2: Tests of averages of the 10 introductions evaluated with respect to the different quality criteria: Relation equatorial diameter - polar diameter (ED / PD), fruit firmness (FF), number of locules (NL), relation fruit firmness number of locules (FF / NL), number of seeds (NS), brix degrees ( $(-$ ), acidity and production per plant in 10 cherry tomato introductions in Manizales, Caldas, Colombia.

\section{Firmness of the fruit (FF)}

The different conditions of both humidity in the substrate and the different levels of salinity influenced the firmness of the fruits (Table 1). The intermediate conditions of humidity and salinity (66\% humidity and $2.5 \mathrm{dS} \mathrm{m}^{-1}$ ) presented the highest firmness indexes, while normal conditions (100\% humidity and $\left.1.5 \mathrm{dS} \mathrm{m}^{-1}\right)$ presented the lowest values (Table 1).

The introduction of the highest average firmness value was IAC426 with average (1217.58 lb.) $26 \%$ higher than the lowest result, in which case was the elite introduction LA1480 (Table 2). It worth noting that all the introductions showed a tendency to increase the firmness in the intermediate conditions of water stress $(66 \%$ humidity) and to decrease gradually as the availability of water decreases.

According to Huang, et al. (2012) [3], the firmness depends on the turgor, cohesion, shape and size of the cells that make up the cell wall, the presence of support tissues and the composition of the fruit. The components of the cell walls that contribute to the firmness are hemicellulose, cellulose and pectin. Therefore, the water deficit contributes to the turgor in the cells decreasing, thus, the greater the turgor the lesser is the firmness of the fruit. The firmness of the pericarp is closely linked to the resistance to transport, avoiding loss of quality due to mechanical damage; most of the current cultivars with good pericarp firmness show resistance to pests and diseases, tolerance to abiotic stress conditions such as salinity, drought, and low and high temperatures.

\section{Number of locules (NL)}

No differences were shown for either the independent factors (introduction - salinity and introduction humidity), nor in their interaction (introduction - salinity - humidity). Salinity conditions of $2.5 \mathrm{dS} \mathrm{m}^{-1}$ and $5 \mathrm{dS} \mathrm{m}^{-}$ ${ }^{1}$ showed the lowest numbers of locules per fruit, and therefore greater firmness (Tables 1 and 2). The introductions with the highest and lowest number of lobes were IAC 1688 and LA 445 respectively (Table 2).

According to Bonilla-Barrientos, et al. (2014) [12], the locules in the fruit confer the kidney shape. These same authors affirm that the "square" or "pepper" type tomatoes excelled in variables of fruit size, soluble solids and firmness, reason why the kidney-shaped fruits or with a greater number of locules have lower values in firmness. Thus, it is possible to confirm that the variable number of locules does not have a directly proportional relation to the firmness in the fruits.

\section{Soluble Solids (SS)}

The highest values of soluble solids were registered for the condition of $66 \%$ humidity with an average of 10.31 and the lowest in the condition of total availability of water (100\% humidity) with an average of 8.48 , with a difference of approximately 2 points (Table 1 ). According to Causs, et al. (2003) [13], the content of soluble solids is the easiest measure of quality linked to sugar content and it has been suggested that it could be the first criterion to classify the quality of cherry tomato fruits. For this reason, it can be established that, in order to guarantee 


\section{Food Science and Nutrition Technology}

that a tomato is considered to be sweet, it must have a percentage of soluble solids equal to or greater than $8^{\circ}$ brix. Thus, a fruit of good quality is one that exceeds the value of $8^{\circ}$ brix, giving it a high quality bonus to those higher values of soluble solids content in the fruits.

According to Renquist, et al. (2005) [14], the low availability of water during the development of the fruits could increase the content of soluble solids in them. On the other hand, the highest salinity condition (5 dS m-1) was the one that recorded the best values of soluble solids content, while the normal salinity condition obtained the lowest values (Table 1 ), even below the $8^{\circ}$ brix.

The above effect can be explained because it has been reported that higher levels of fertilizers or salinity in irrigation water increase the levels of soluble solids in tomatoes and peppers grown under protected conditions (Mori, et al. 2008) [15]. Likewise, these authors suggest that, in addition to electrical conductivity, there is evidence that nitrogenous nutrition can affect the levels of soluble solids in an indirect and complex manner. The availability of nitrogen can affect the efficiency of sugarproducing photosynthesis, thereby altering the levels of soluble solids. In the case of humidity-salinity interaction, the best treatments in terms of soluble solids content results were those with the highest salinity $\left(5 \mathrm{dS} \mathrm{m}^{-1}\right)$, with their respective humidity levels $(100 \%, 66 \%$ and $33 \%$ ). Conversely, the lowest salinity condition (1.5 dS m1) were the fruits that showed the lowest concentration of soluble solids in an average of $6.07^{\circ}$ brix (Table 2). It is evident that the higher the salinity, the higher the content of soluble solids in the fruits and, consequently, fruits with better taste are obtained.

According to Goykovic \& Saavedra (2007) [16], the positive effects of salinity in the plants of tomato cultivated are the improvement of the organoleptic and biological quality of the fruits, since they have a higher content of soluble solids, acidity and carotenoid pigments. Regarding the introductions, those that had better behavior were accessions IAC 1621 and the CONTROL, both surpassing values of $10^{\circ}$ brix. The introduction that registered the lowest content of soluble solids was LA 445 (Table 2).

\section{Titratable Acidity}

Higher availability of organic acids was reportedfor humidity conditions of $66 \%$ and $33 \%$ with respect to the $100 \%$ humidity condition, which gave the lowest values of titratable acidity (Table 1 ). The salinity condition that showed the highest acid content was the maximum level tolerated by the plant of $5 \mathrm{dS} \mathrm{m}^{-1}$, with $55 \%$ more organic acid content compared to a normal plant development condition (1,5 $\left.\mathrm{dS} \mathrm{m}^{-1}\right)$ (Table 1$)$.

Regarding the introductions under the different evaluated conditions, there was no difference in the values of acidity of the fruits (Table 2).

\section{Production per plant (PPP)}

The highest values of production per plant were presented for the treatment of $100 \%$ water availability with an average of 403.9 grams per plant, decreasing significantly as water availability was lower, to the point of decreasing production to a $62 \%$ per plant in the treatment of $33 \%$ humidity. Likewise, the salinity treatment that had the best response in terms of production was that of normal conditions of electrical conductivity $\left(1.5 \mathrm{dS} \mathrm{m}^{-1}\right)$, since it had an average production per plant of 686 grams, while as the electrical conductivity increased, production decreased significantly up to $89 \%$ (74.86 g plant $\left.^{-1}\right)$ with respect to production under normal conditions (Table 1).

The elite introductions that presented the best production were IAC 1686 and IAC 1688, with average productions per plant of $498 \mathrm{~g}$ and $428 \mathrm{~g}$, respectively. The elite introductions with the lowest productions per plant were LA 1480 with an average of $82.4 \mathrm{~g}$ with $83 \%$ less than the production for introduction of IAC 1686 (Table 2).

According to Monge-Pérez (2014) [17], the yield per plant oscillates between 803 and 3,224 grams, and the yield per hectare varies between 20.85 and 83.73 ton / ha. For the parameters of this study, with distances of $30 \mathrm{~cm}$ between plants and $30 \mathrm{~cm}$ between rows, with a planting density of 111,111 plants / ha, the yield of the accession with the best production (IAC 1686) was 55.3 ton / ha, which is within the range mentioned above.

As the availability of water decreased and the electrical conductivity increased, the yields for each material decreased considerably, while the control material (Sweet Million) was the one that obtained the best performance for this variable, since it was the most stable and with promising yield despite these declining as the stress increased.

Among the studies that analyze the productivity and the quality of the fruits is worth noting the study carried out by Magan, et al. (2008) [18], evaluating the effect of salinity on fruit production, production components and quality of tomato fruits grown in vegetation houses under Mediterranean climate conditions. They found that the 


\section{Food Science and Nutrition Technology}

increase in salinity improved several aspects of fruit quality, such as: (i) the proportion of "extra" fruit (high visual quality), (ii) the content of soluble solids and (iii) the content of titratable acidity. However, salinity decreased the size of the fruits, which is one of the main price determinants. In the economic analysis, the value of the increase in the visual quality of the fruits was compensated by the reduction in the yield and smaller size of the fruit.

The effects of salinity stress in melon induce lower phytomass production, lower concentration of chlorophyll in leaves and lower productivity [19]. This is in agreement with the results found in previous investigations with strawberry [20] and cucumber [2123]. Therefore, it is perceived that salinity can affect diverse cultures in different ways such as growth, productivity, and the quality of the fruits.

In general, the alterations in the characteristics of quality of the fruits of the elite cherry tomato introductions produced under water and saline stress conditions have an increase in the content of soluble solids, by the action of the phase of the plants exposed to salinity. In this way, changes in the characteristics of the fruits may be influenced by environmental conditions, varieties or hybrids, soil type, type of crop conduction and the phenological stage in which stress occurs, however more studies are necessary in that sense.

Generally, the introduction of the laser products in the laser products of the cherry producers is a great source of condensers and preservatives, presenting a large number of solutions in the field of planting, as well as the plant's expansion of plants. A la salinidad. In the form of statistics, the cosmic lashes are in the frames of the effects, the differential of the hibiscus, the type of soil, the type of cultivation and phenological stage or quire stress, however more studies are necessary in that sense.

\section{Conclusions}

The production limit of the 10 introductions evaluated was up to $5 \mathrm{dS} \mathrm{m}^{-1}$ of electrical conductivity.

High levels of salinity and water stress promote the increase of soluble solids in cherry tomato fruits, with a decrease in production as abiotic stress increases.

Elite introductions IAC 1686 and IAC 1688 presented the best average production per plant with $498 \mathrm{~g}$ and 428 $\mathrm{g}$, respectively, proving to be promising for its genetic variability for tolerance to salinity at the level of wild species, a fact that leads to the realization of future research.

\section{References}

1. Fritsche-Neto R, Do Vale J, PC CAVATTE (2011) Melhoramento para tolerância a estresses ou para eficiência no uso de recursos?. In: Fritsche-Neto R \& A Borem (Ed.). Melhoramento de plantas para condições de estresse abióticos. Viconde do Rio Branco: suprema: 250p.

2. Ribeiro MS, Barros MF, MBG Santos (2009) Química dos solos salinos e sódicos. In: Melo V \& LRF Alleoni (Ed.). Química e mineralogia do solo. Parte II Aplicações. Viçosa: Sociedade Brasileira de Ciência do solo. 449-484p.

3. Huang $\mathrm{CH}$, Zong L, Buonanno $\mathrm{M}$, Xue $\mathrm{X}$, Wang $\mathrm{T}$, et al. (2012) Impact of saline water irrigation on yield and quality of melon (Cucumismelo cv. Huanghemi) in northwest China. European Journal of Agronomy 43: 68-76.

4. Ashraf M, MR Foolad (2007) Roles of glycine and proline in improving plant abiotic-stress resistance. Envoronmetal and Experimental Botany 59(2): 206216.

5. Pessarakli M, I Szabolcs (1999) Soil salinity and sodicity as particular plant/crop stress factors. In: Pessarakli M (Ed.). Handbook of plant and crop stress. New York: Marcel Dekker: 1-15p.

6. Soil Science Society of America (2008) Glossary of soil science terms. Madison: American Society of Soil Science pp: 88.

7. Fageria NK, Soares Filho W, HR Gheyi (2010) Melhoramento genético vegetal e seleção de cultivares tolerantes a salinidade. In: Gheyi HR, Dias N \& CF LACERDA (Ed.) Manejo da salinidade na agricultura: Estudos básicos e aplicados. Fortaleza: Instituto Nacional de Ciencia e Tecnologia em Salinidade "INCTSal": 205-218 p.

8. Niu G, Rodriguez DS, Call E, Bosland PW, Ulery A, et al. (2010). Responses of eight chile peppers to saline water irrigation. Scientia Horticulturae 126(2): 215222.

9. Chinnusamy V, Jagendorf A, Jian-Kang Z (2005) Understanding and Improving Salt Tolerance in Plants. Crop Science 45: 437- 448. 
10. Daryanto S, Wang L, Jacinthe P (2015) Global Synthesis of Drought Effects on Food Legume Production.

11. Bonilla-Barrientos O, Lobato-Ortiz R, García-Zavala J, Cruz-Izquierdo S, Reyes-López D, et al. (2014) Diversidad agronómica y morfológica de tomates arriñonados y tipo pimiento de uso local en Puebla y Oaxaca, México. Revista fitotecnia mexicana 37(2): 129-139.

12. Hurtado-Salazar A, Silva DFP, Sediyama CS, Bruckner CH (2015) Caracterização física e química de frutos de maracujazeiro-amarelo enxertado em espécies silvestres do gênero passiflora cultivado em ambiente protegido. Revista Brasileira de Fruticultura 37(3): 635-643.

13. Causse M, Buret K, Robini P, P Verschave (2003) Inheritance of Nutritional and Sensory Quality Traits in Fresh Market Tomato and Relation to Consumer Preferences. Journal of food science 68(7): 23422350.

14. Renquist AR, LaGrange BP, JB Reid (2005) Towards a control theory for acidity of vegetable crops. Acta Hort 694: 463-469.

15. Mori M, Amato M, Di Mola I, Caputo R, Quaglietta FC, et al. (2008). Productive behaviour of "cherry"-type tomato irrigated with salinewater in relation to nitrogen fertilization. European Journal Agronomy 29: 135-143.

16. Goykovic V, G Saavedra (2007) Algunos efectos de la salinidad en el cultivo del tomate y prácticas agronómicas de su manejo. Revista Idesia (Chile) 25(3): 47-58.
17. Monge-Perez J (2014) Characterization of 14 tomato genotypes (Lycopersicon esculentum Mill.) Grown under greenhouse in Costa Rica. Tecnología en Marcha 27(4): 58-68.

18. Magan JJ, Gallardo $\mathrm{M}$, Thompson RB, Lorenzo $\mathrm{P}$ (2008). Effects of salinity on fruit yield and quality of tomato grown in soil-less culture in greenhouses in Mediterranean climatic conditions. Agricultural water management 9(5): 1041-1055.

19. Kaya C, Tuna L, Ashraf M, Altunlu H (2007) Improved salt tolerance of melon (Cucumismelo L.) by the addition of proline and potassium nitrate. Environmental and Experimental Botany 60(3): 397403.

20. Kaya C, Kirnak H, Higgs D (2001) An experiment to investigate the ameliorative effects of foliar potassium phosphate sprays on salt stressed strawberry plants. Australian Journal of Agricultural Research 52: 995-1000.

21. Kaya C, Higgs D, Ince F, Amad BM, Cakir A, et al. (2003) Ameliorative effects of potassium phosphate on salt stressed pepper and cucumber. Journal Plant Nutrition 26(4): 807-820.

22. Fageira NK, Stone LF, AB Santos (2011) Melhoramento para tolerância a salinidade. ?. In: Fritsche-Neto R \& A Borem (Ed.). Melhoramento de plantas para condições de estresse abióticos. Viconde do Rio Branco: suprema: 250p.

23. Zúñiga OE, Osorio JC, Cuero RG, Peña JA (2012). Evaluación de tecnologías para la recuperación de suelos degradados por salinidad. Revista Facultad Nacional de Agronomía Medellín, [S.l.] 64(1): 57695779.



